\section{Carly Smith}

Department Marketing and Retail Management, University of South Africa Email: prinsck@unisa.ac. za (corresponding author) ORCID: http://orcid. org/0000-0003-46343503

Prof. Johannes A. Wiid Department Marketing and Retail Management, University of South Africa Email: jwiid@unisa.ac.za ORCID: http://orcid. org/0000-0002-2195$532 X$

DOl: https://dx.doi. org/10.18820/24150525/ Comm.v24.7

ISSN 2415-0525 (Online)

Communitas 2019 24: 1-17

Date submitted:

20 August 2019

Date accepted:

25 October 2019

Date published:

03 Desember 2019

(c) Creative Commons With Attribution (CC-BY)

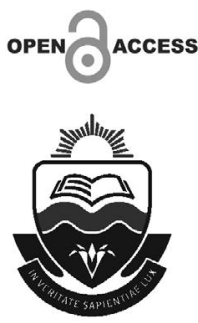

THE CHARACTERISTICS OF E-NEWSLETTERS IN PREDICTING HIGHER EDUCATION INSTITUTION EMPLOYEES' USAGE

\section{ABSTRACT}

E-newsletters provideorganisationalinformation andemployee engagement opportunities to overcome behavioural and communication isolation in departments within an organisation. By optimising e-newsletters, employees can better utilise the content of the e-newsletter to perform their daily operational tasks and to fulfil organisational goals and objectives. In order to convey the organisational information in an e-newsletter, it needs to be delivered in an appealing manner regarding content, layout, ease of navigation, quality of photographs, and inspirational messages or quotes. The purpose of this study was to determine employees' perceptions of e-newsletters based on their characteristics relating to content, layout, ease of navigation, quality of photographs, and inspirational messages. A quantitative, self-administered web-based survey was disseminated to employees of a higher education institution in South Africa. The results indicate that the frequency of receiving e-newsletters and personal touches to the e-newsletter affect employees' perception of e-newsletters. This research highlights the importance of including information in an e-newsletter that appeals to employees on a personal level.

Keywords: corporate communication; organisational communication; strategic communication; e-newsletters; internal communication; e-newsletters; higher education

\section{INTRODUCTION}

Support departments often provide the most essential services for the continued working of core functions within an organisation. When support departments are secretive about their workings and in turn create negative attitudes and behaviours in the core functions, this generates great discontent amongst employees and management alike (Gressgård et al. 2014: 639-640).

For an organisation to operate optimally with the resources at hand it requires its employees to be fully informed of their roles within the organisation and it requires employees to make the most of the typical eight-hour workday to complete 
their work tasks. An obstacle to employees being fully informed is communicating with them without disrupting their productivity. Another obstacle is how to bridge the gap between departments within a large organisation, which have to work together, but do not have the time to have inter-departmental meetings to discuss how to go about the relay of work between the departments. These obstacles are overcome by making use of e-newsletters, which can provide a platform for communication regarding the inner workings of particular departments to enable supporting departments to understand what it takes to get the work done (Kowlaski 2011: 136; Little 2011; Gressgård et al. 2014).

The purpose of organisational information is lost when employees are bombarded with a surplus of information that leads to information overload. To facilitate reading organisational information, which is distributed via e-newsletters, the e-newsletter needs to be easy to read and user-friendly (Vidgen et al. 2011: 85). A poorly designed e-newsletter, in addition to information overload, could contribute to employees' unwillingness to use the e-newsletter for the purpose it serves (ibid.). Thus, it is vital that the characteristics of the e-newsletter are conducive for easy reading and that it has an appealing nature.

For the purpose of this study, the variable of perceived usefulness was utilised as the design characteristics of an e-newsletter are essential considering that how well an e-newsletter reads will affect readership rates. The study aimed to answer the following research question: To what extent do the characteristics of an e-newsletter contribute to the use of e-newsletters, and are the characteristics equally important to the employees when reading the e-newsletter?

\section{LITERATURE REVIEW}

\section{Internal communication}

Internal communication is the combined efforts by the organisation to share organisational information with employees, garner employees' support for organisational goals and objectives, and to synchronise departmental tasks to achieve those organisational goals and objectives (Men 2014: 256; Smith 2013: 173). When employees are engaged by the organisation, greater levels of organisational citizenship behaviour, customer satisfaction and employee retention are evident. Employees are also more likely to be attentive and dedicated, feel a connection to the organisation, be willing to work longer hours when needed, and to contribute to the organisational goals (Men \& Hung-Baesecke 2015: 448). Given the improved productivity levels when employees are engaged, internal communication has become essential when it promotes commitment to the organisation and an understanding of the organisation's ever-changing aims, and creates a sense of employee belonging and awareness of the organisations fluctuating environments (Welch 2015: 390).

For internal communication to be successful, an appropriate communication channel is required. With technological advances, there has been a change in the 
organisational communication landscape - ranging from traditional communication channels, including print media, face-to-face meetings, e-mails and telephone calls, to internet-based communication, which entails intranets, blogs and social networking sites. The most commonly used internal communication channel is the e-newsletter.

\section{E-newsletters}

Electronic newsletters, or e-newsletters, are the electronic form of paper-based newsletters (Molenaar 2012: 111). E-mail has made it easier to send newsletters electronically as all employees who have personalised organisational e-mail addresses are able to receive e-newsletters (Kowlaski 2011: 136). E-newsletters' information dissemination is achieved through the creation, distribution and application of knowledge in organisations (Dixon 2012: 11). E-newsletters typically have a number of objectives: breaking down silos, reducing email overload, and reinforcing other communication (Snapcomms 2017). The main objective of e-newsletters is to inform employees of relevant organisational information pertaining to the organisation's goals and objectives, employees' roles, current corporate news, training courses, community outreach projects, and corporate financial information and change in policies.

A newsletter is relevant when valuable content is included in the newsletter, such as engaging articles, resources, latest news and trends, and links to content on the organisation's main website (Jefferson \& Tanton 2015: 90). The characteristics of e-newsletters, discussed in the subsequent section, refer to content, layout, ease of navigation, quality of photographs, and inspirational messages or quotes ("thought for the day"). In addition, the matter of frequency of distributing or delivering e-newsletters to employees is discussed. Limited research exists on the characteristics of e-newsletters on research databases, such as EbscoHost Academic Search Premier, Nexus, Sage Journals Online, Scopus, and Taylor and Francis Online; thus, material produced by industry experts was utilised for the following discussion.

\section{Characteristics of e-newsletters}

\section{Quality of photographs}

E-newsletters must be photograph-rich as it enhances the e-newsletter, especially when the articles cover particular stories such as employee achievements (Murphy 2014). In addition, when brand-aligned photographs or images are included it reinvigorates the content and can increase click-through rates (Modlabs 2014). To achieve click-through rates, photographs must be aligned to the subject title and the text; otherwise, it will simply be an irrelevant inclusion in the e-newsletter. Furthermore, size matters, as a large photograph can slow down the download time (especially when the e-newsletter is accessed through a mobile device or on a tablet). If a photograph is too small, it can be difficult to view because of poor pixel quality. High-resolution photographs appear crisp in e-newsletters, whereas low-resolution photographs often look unclear and detract from their purpose (Mailbakery.com 2015). 


\section{Content}

The content of an e-newsletter depends on the organisational mission statement, goals and objectives. The content is based on the organisational values and principles that the organisation wishes to convey to employees (Newsom \& Haynes 2011: 88). An e-newsletter's content should be aligned to the organisational goals, which provides the tone and direction of electronic communication with employees. In addition, e-newsletters should be aligned to the communication objectives, which provide a focus, a tactical standard for consistency, an indication of the duration to complete goals, and strategic organisational scope (Fourie 2014: 170).

E-newsletters should be centred on the audience, which in this case are the employees. Thus, when an e-newsletter is designed properly, it can encourage employees to be more active in the cultural and work organisational environment (Kaufman 2016). Therefore, e-newsletters should include information that affects the employee in terms of product launches or new policy changes. Moreover, an employee spotlight section recognises and creates awareness about employees regarding the excellent service they provide (Furgison 2017). An e-newsletter can boost morale and motivate employees when they are reminded of the quality products and service that the organisation delivers; thus, reminding employees that they are part of an organisation that thrives.

\section{Layout}

An e-newsletter should have a consistent structure so that employees are always aware of what to expect in terms of sections/divisions (Furgison 2017). The e-newsletter design should be a good balance between minimal, relevant text and photographs or images (Everlytic 2015). Tracking how employees read the e-newsletter gives a good indication of where to place the most important information. As seen in examples of e-newsletters, the majority of the clicks occurred above the fold, which is where the organisation can place their most pertinent articles. Further layout additions include (Dixon 2012: 16-17; Molenaar 2012: 111-112; Everlytic 2016: 1):

- Short messages (minimum of five lines) and a link that can be clicked on for further information.

- Provide an interaction possibility (response), but also a possibility to prevent the receipt of further messages.

- The newsletter is highly visual, with imagery and content that leads.

- The design should be about engagement, compelling the reader to take the next step in clicking on the call-to-action link of the e-newsletter.

- Relate the e-newsletter to the organisation's website in terms of the design.

\section{Ease of navigation}

Consistent navigation should be evident both in terms of how the e-newsletter appears but also in terms of where it appears. Promote ease of use by having easy to find information, which remains the same over time so as not to confuse employees who 
are used to a particular navigation (De Greyter 2012). In addition, if an e-newsletter has particular categories or divisions, then clearly indicate the differences through categories or sub-categories, which are clearly and visually defined, and have accurate navigational titles. It is also important to ensure that the search function works so that the employees are able to find the relevant results. Functionality of the e-newsletter should allow the reader to find current articles, as well as past editions of the e-newsletter (Snapcomms 2017). As full articles cannot be included in the e-newsletter, it is thus necessary for a call-to-action button, which leads to more information. This call-to-action button or highlighted text should be clearly visible.

\section{Inspirational messages}

A personal note gives the e-newsletter a more appealing nature (Everlytic 2015). Inspirational quotes are powerful tools in internal communication as these capture the mood, aspiration and ideals of the organisation. These messages can enliven the organisational policy, as long as the quote is pertinent to the policy. Inspirational quotes in the form of a "thought for the day" can inspire and motivate employees and form part of the internal communication to boost morale, albeit in a small measure (MyHub 2017). By engaging with employees, an organisation and its management team can increase productivity (Grossman 2016).

\section{Frequency of e-newsletter distribution}

With the advances in technology, internal communication is distributed more easily and instantaneously, with increased speed of communication and frequency (Paxson 2010: 3). Internal communication, in particular e-newsletters, can be sent with a number of attributes, which include documents, worksheets, and links to other sites, photographs or attachments (Kinzey 2013: 156). In the creation of e-newsletters, decisions are made on what the e-newsletter will include in terms of content and photographs; how the e-newsletter will be distributed; at which frequency the e-newsletter will be distributed; what the overall design of the e-newsletter will look like; and how it will be delivered to the employees (Hume 2010: 8, Smith 2013: 229).

\section{RESEARCH METHODOLOGY}

\section{Procedure and design}

The study was exploratory in nature and adopted a quantitative approach, with a cross-sectional design. Data was collected from employees at a South African higher education institution through a self-administered web-based survey, which is in line with the online delivery of e-newsletters. The respondents were selected based on the role of a university's research outputs and resulting innovation, which affects private organisations and public research institutions (Nyerere \& Friso 2013: 663-664).

Respondents were required to rate the importance of the following characteristics of e-newsletters in general, as well as in relation to the specific e-newsletter of the higher institution itself, on a 5-point Likert-scale ranging from 1 - "very unimportant" to 5 - "very important": 

a) Content
b) Layout
c) Ease of navigation
d) General quality of photographs
e) Inspirational message/"thought for the day"

The characteristics of e-newsletters in general in predicting wanting to receive an e-newsletter and the characteristics of the institutional e-newsletter in predicting wanting to receive the institutional e-newsletter were both examined in order to compare whether similar models and characteristics could be identified in predicting whether respondents would like to receive e-newsletters or not. Furthermore, respondents were also required to indicate whether they want to receive an e-newsletter or not, the frequency of use of e-newsletters, the preferred frequency of receiving an e-newsletter, and their perception regarding the importance of a daily or weekly e-newsletter in terms of organisational information.

\section{Sample}

The overall sample for the study consisted of 404 respondents. The majority of the sample were female $(59.7 \%, n=241)$, with $34.9 \%(n=141)$ male. Table 1 provides a detailed breakdown of the demographics of the sample.

TABLE 1: DEMOGRAPHIC BREAKDOWN OF SAMPLE

\begin{tabular}{|c|c|c|}
\hline Gender & $\mathbf{n}$ & Percentage \\
\hline Male & 141 & 34.9 \\
\hline Female & 241 & 59.7 \\
\hline Missing & 22 & 5.4 \\
\hline Age & & \\
\hline $18-25$ & 2 & 0.5 \\
\hline $26-35$ & 90 & 22.3 \\
\hline $36-45$ & 109 & 27.0 \\
\hline $46-65$ & 201 & 49.8 \\
\hline $65+$ years & 2 & 0.5 \\
\hline Term of employment & & 29.0 \\
\hline Less than 5 years & 117 & 27.5 \\
\hline $5-10$ years & 111 & 11.1 \\
\hline $11-15$ years & 45 & 31.4 \\
\hline More than 15 years & 127 & 1.0 \\
\hline Missing & 4 & \\
\hline
\end{tabular}




\section{Data analysis}

Data was analysed using basic descriptive statistics, as well as logistic regression analysis, utilising the Statistical Package for the Social Sciences 22 (SPSS 22). The enter method was utilised for the logistic regression analysis (all predictor variables entered into the model simultaneously) because of the explorative nature of the study.

\section{FINDINGS AND RESULTS}

The findings are presented by firstly examining the results of the logistic regression analysis based on the characteristics of e-newsletters in general. Following this, the results of the logistic regression, focussing on the characteristics of the specific e-newsletter from the higher education institution where respondents are employed, are examined. Finally, additional factors associated with the reception and the use of e-newsletters will be examined.

\section{Logistic regression analysis: e-newsletter characteristics in general}

For the purpose of the logistic regression model concerning e-newsletter characteristics in general, "wanting to receive an e-newsletter or not" was included as the categorical criterion variable with content, layout, ease of navigation, quality of photographs and "thought for the day" included as predictor variables. Overall, 83.9\% $(n=339)$ of the respondents within the sample indicated that they want to receive an e-newsletter, with $16.1 \%(n=65)$ of the respondents indicating that they do not want to receive an e-newsletter.

TABLE 2: MEAN RATINGS FOR E-NEWSLETTER

CHARACTERISTICS IN GENERAL

\begin{tabular}{|c|c|}
\hline Predictor & Mean \\
\hline Content & 4.06 \\
\hline Layout & 3.90 \\
\hline Ease of navigation & 4.16 \\
\hline Quality of photographs & 3.88 \\
\hline Thought for the day & 3.39 \\
\hline
\end{tabular}

Overall, all the characteristics of e-newsletters in general were rated above average by the respondents, with mean ratings for all the characteristics of e-newsletters in general $>3$ (see Table 2). Hence, all the characteristics were deemed "important" by the respondents. 
TABLE 3: HOSMER AND LEMESHOW GOODNESS-OF-FIT TEST FOR CHARACTERISTICS OF E-NEWSLETTERS IN GENERAL

\begin{tabular}{c|c|c}
\hline Chi-square & df & Sig. \\
\hline 4.729 & 8 & .786 \\
\hline
\end{tabular}

Note: Model $X^{2}(5)=66.534, p<.001$

In terms of goodness-of-fit, the Hosmer and Lemeshow statistic was found to be nonsignificant with $p=.786(p>.05)$, indicating that the model was a good fit for the data (see Table 3). The overall model chi-square was also found to be significant $(p<.001)$, further indicating that the model improves prediction and that it provides a good fit (Field 2005; Hair et al. 2010).

TABLE 4: PREDICTORS FOR RECEIVING E-NEWSLETTER IN GENERAL

\begin{tabular}{|c|c|c|c|c|c|c|}
\hline Predictor & B & SE & Wald & Sig. & $\begin{array}{c}\text { Exp(B) } \\
\text { Odds } \\
\text { Ratio }\end{array}$ & Cl (95\%) \\
\hline Content & .386 & .296 & 1.704 & .192 & 1.471 & $.824-2.625$ \\
\hline Layout & .404 & .264 & 2.337 & .126 & 1.497 & $.892-2.511$ \\
\hline Ease of navigation & -.591 & .286 & 4.271 & .051 & .554 & $.316-.970$ \\
\hline Quality of photographs & .305 & .217 & 1.974 & .160 & 1.357 & $.886-2.076$ \\
\hline Thought for the day & .697 & .137 & 25.771 & $.000^{* *}$ & 2.008 & $1.534-2.629$ \\
\hline
\end{tabular}

** Significant at the $p<.001$ level

Of the predictors entered into the model, only the inspirational quote or "thought for the day" was found to be a significant predictor of whether the respondents wanted to receive a newsletter or not, with $b=.697$, Wald $x 2(1)=25.77, p<.001$ (see Table 4). None of the other predictors was found to be significant in predicting whether or not the respondents would like to receive an e-newsletter or not ( $p>.05)$ (see Table 4). The odds ratio $(\operatorname{ExpB})$ for the predictor "thought for the day" was found to be greater than 1 , indicating that an increase in the predictor would increase the likelihood of wanting to receive an e-newsletter (see Table 4) (Field 2005; Hair et al. 2010). 
TABLE 5: OBSERVED AND PREDICTED FREQUENCIES FOR RECEIVING E-NEWSLETTERS OR NOT: E-NEWSLETTERS IN GENERAL

\begin{tabular}{|c|c|c|c|}
\hline \multirow{2}{*}{ Observed } & \multicolumn{2}{|c|}{ Predicted } & \multirow{2}{*}{ \% Correct } \\
\cline { 2 - 3 } & Yes & No & \\
\hline Yes & 333 & 6 & 98.2 \\
\hline No & 46 & 19 & 29.2 \\
\hline Overall \% correct & & & 87.1 \\
\hline
\end{tabular}

Note: Cut value $=.5$

The overall model ensured that $87.1 \%$ of the cases were classified correctly (see Table 5); $98.2 \%$ of cases falling in the "yes" category (want to receive an e-newsletter in general) was classified correctly, whilst $29.2 \%$ of the cases falling within the "no" category (do not want to receive an e-newsletter in general) was classified correctly (see Table 5). The model thus seems to be more accurate in predicting wanting to receive an e-newsletter in general, as opposed to not wanting to receive an e-newsletter.

\section{Logistic regression analysis: institutional e-newsletter characteristics}

Similar to the above for general characteristics of e-newsletters, "wanting to receive an e-newsletter or not" was included as the categorical criterion variable with content, layout, ease of navigation, quality of photographs and "thought for the day" included as predictor variables for the logistic regression model related specifically to the characteristics in relation to the specific institutional e-newsletter. Overall, $83.9 \%$ $(n=339)$ of the respondents within the sample indicated that they want to receive an e-newsletter, with $16.1 \%(n=65)$ of the respondents indicating that they do not want to receive an e-newsletter.

TABLE 6: MEAN RATINGS FOR INSTITUTIONAL E-NEWSLETTER CHARACTERISTICS

\begin{tabular}{|c|c|}
\hline Predictor & Mean \\
\hline Content & 4.08 \\
\hline Layout & 3.87 \\
\hline Ease of navigation & 4.06 \\
\hline Quality of photographs & 3.74 \\
\hline Thought for the day & 3.27 \\
\hline
\end{tabular}


All the characteristics of the institutional e-newsletter were rated above average by the respondents with mean ratings for all the characteristics of the institutional e-newsletter $>3$ (see Table 6). All the characteristics were thus rated as "important" by the respondents overall, if the means are considered.

TABLE 7: HOSMER AND LEMESHOW GOODNESS-OF-FIT TEST FOR INSTITUTIONAL E-NEWSLETTER CHARACTERISTICS

\begin{tabular}{|c|c|c|}
\hline Chi-square & df & Sig. \\
\hline 5.988 & 8 & .649 \\
\hline
\end{tabular}

Note: Model $X^{2}(5)=49.069, p<.001$

The Hosmer and Lemeshow goodness-of-fit test was found to be non-significant for the model with $p>.05$ indicating a good fit for the model to the data (see Table 7). Furthermore, a significant overall model chi-square square was found $(p<.001)$, indicating that the model improves prediction and is a good fit for the data (Field 2005; Hair et al. 2010).

TABLE 8: PREDICTORS FOR RECEIVING INSTITUTIONAL E-NEWSLETTERS

\begin{tabular}{|c|c|c|c|c|c|c|}
\hline Predictor & B & SE & Wald & Sig. & $\begin{array}{c}\text { Exp(B) } \\
\text { Odds } \\
\text { Ratio }\end{array}$ & Cl (95\%) \\
\hline Content & .089 & .262 & .116 & .733 & 1.093 & $.654-1.826$ \\
\hline Layout & .508 & .285 & 3.180 & .075 & 1.662 & $.951-2.903$ \\
\hline Ease of navigation & -.545 & .280 & 3.773 & .052 & .580 & $.335-1.005$ \\
\hline Quality of photographs & .177 & .202 & .766 & .381 & 1.193 & $.803-1.772$ \\
\hline Thought for the day & .561 & .124 & 20.544 & $.000^{* *}$ & 1.753 & $1.375-2.234$ \\
\hline
\end{tabular}

** Significant at the $p<.001$ level

In line with the previous model concerning the characteristics of e-newsletters in general, only "thought for the day" was found to be a significant predictor of whether respondents wanted to receive a newsletter or not, with $b=.561$, Wald $\times 2(1)=$ $20.54, p<.001$ (see Table 8) for the current model relating to the specific institutional e-newsletter characteristics. The other predictors in the model were all found to be non-significant in predicting whether or not respondents would like to receive an e-newsletter or not $(p>.05)$ (see Table 8). An odds ratio (ExpB) of 1.753 was found for the predictor "thought for the day", indicating that an increase in the predictor will increase the likelihood of wanting to receive an institutional e-newsletter (see Table 8) (Field 2005; Hair et al. 2010). 
TABLE 9: OBSERVED AND PREDICTED FREQUENCIES FOR RECEIVING E-NEWSLETTERS OR NOT: INSTITUTIONAL E-NEWSLETTERS

\begin{tabular}{|c|c|c|c|}
\hline \multirow{2}{*}{ Observed } & \multicolumn{2}{|c|}{ Predicted } & \multirow{2}{*}{ \% Correct } \\
\cline { 2 - 3 } & Yes & No & \\
\hline Yes & 339 & 0 & 100.0 \\
\hline No & 57 & 8 & 12.3 \\
\hline Overall \% correct & & & 85.9 \\
\hline
\end{tabular}

Note: Cut value $=.5$

Overall, the model ensures that $85.9 \%$ of the cases can be classified correctly (see Table 9). Furthermore, $100 \%$ of cases falling in the "yes" category (want to receive an institutional e-newsletter) were classified correctly, whilst only $12.3 \%$ of the cases falling within the "no" category (do not want to receive an institutional e-newsletter) were classified correctly (see Table 9). The model thus seems to be predict wanting to receive an institutional e-newsletter more accurately than not wanting to receive an institutional e-newsletter.

\section{Additional factors related to reception and use of e-newsletters}

In order to further examine factors that may impact on whether respondents would like to receive an e-newsletter or not and on their use of e-newsletters, the respondents were required to indicate whether or not they prefer other channels of communication, the preferred time for receiving the e-newsletter, the frequency of use and reception of an e-newsletter, and the importance of daily or weekly e-newsletters for organisational communication.

Preference for other communication channel

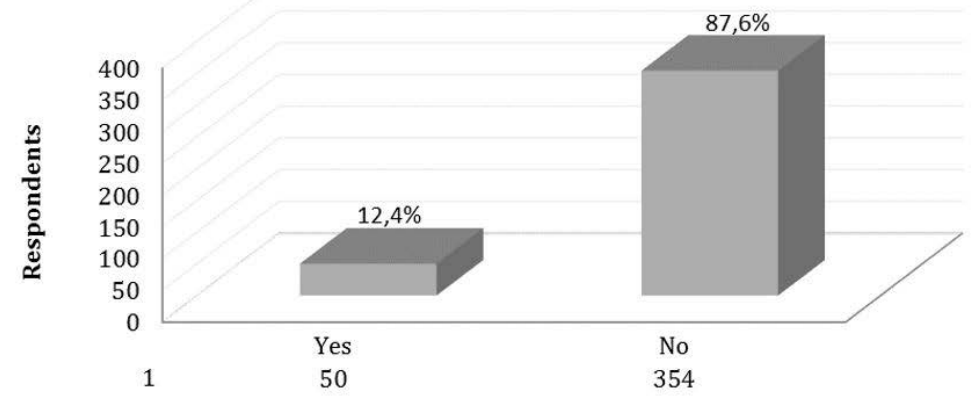

FIGURE 1: PREFERENCE FOR ALTERNATIVE COMMUNICATION CHANNEL TO E-NEWSLETTERS 
The majority of the respondents $(87.6 \%, \mathrm{n}=354)$ indicated that they do not want to receive communication via a different channel than an e-newsletter, with only $12.4 \%$ $(n=50)$ of the respondents indicating otherwise (see Figure 1).

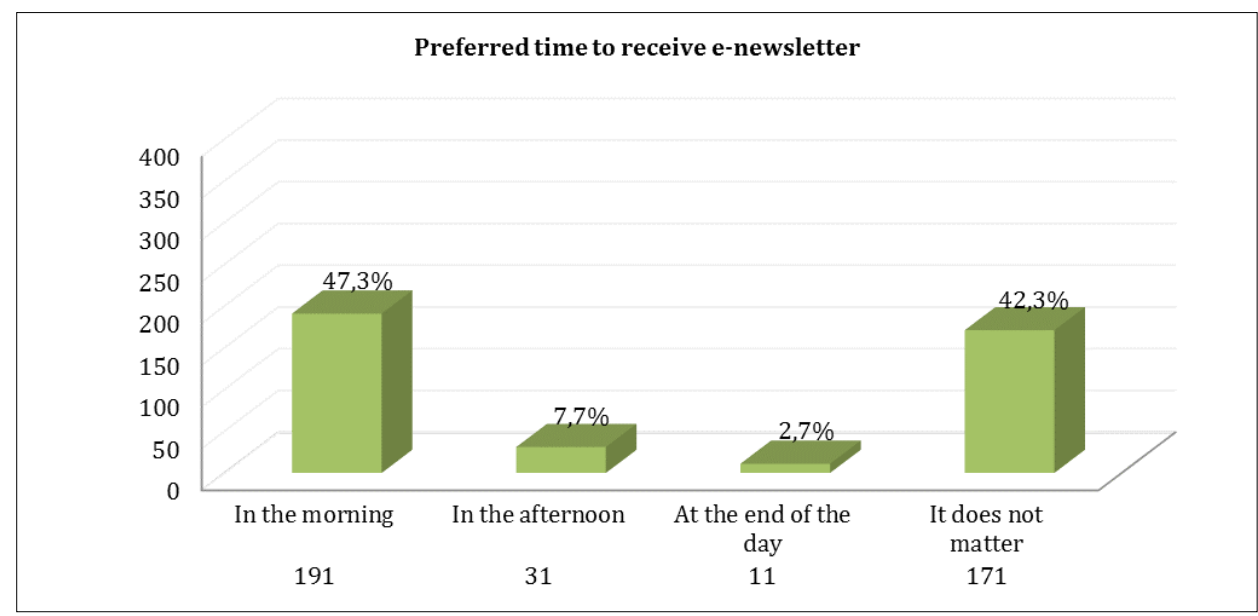

FIGURE 2: PREFERRED TIMES FOR RECEIVING AN E-NEWSLETTER

In terms of the preferred times identified by the respondents for receiving e-newsletters, they predominantly identified early in the morning $(47.3 \%, n=191)$ as the preferred time, with $42.3 \%(n=171)$ of the respondents indicating that it does not really matter when they receive the e-newsletter (see Figure 2). Thus, some ambivalence seems to exist regarding the preferred time for receiving e-newsletters.

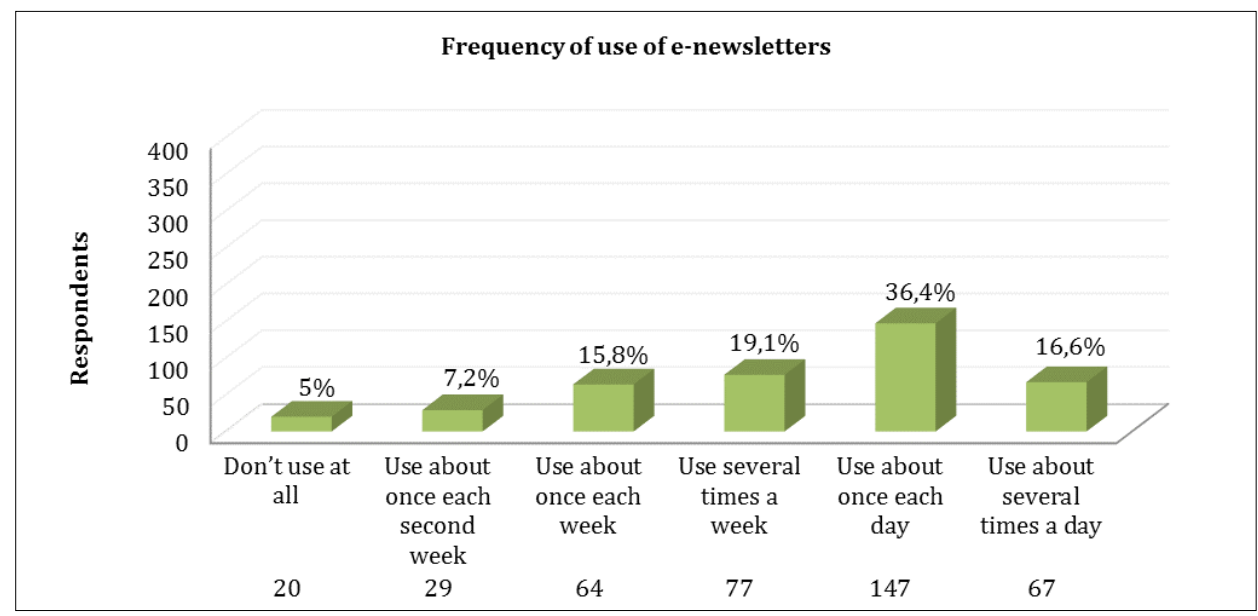

\section{FIGURE 3: FREQUENCY OF USE OF E-NEWSLETTERS}

In terms of the reported frequency of use of e-newsletters by the respondents, the majority $(36.4 \%, n=147)$ indicated that they use the e-newsletter about once a day, 
followed by several times a week $(19.1 \%, n=77)$, and several times a day $(16.6 \%$, $\mathrm{n}=67$ ). The respondents thus seem to display a high frequency of use for e-newsletters (see Figure 3).

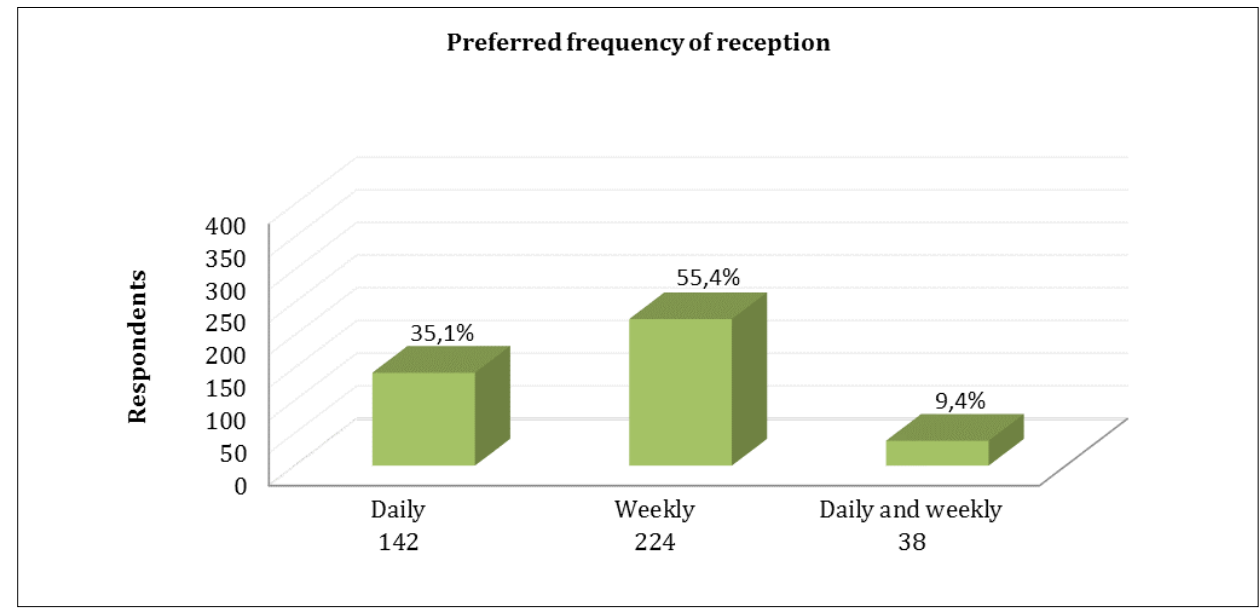

\section{FIGURE 4: PREFERRED FREQUENCY OF RECEPTION}

In line with the above, the majority of the respondents $(55.4 \%, \mathrm{n}=224)$ indicated that they preferred receiving an e-newsletter once a week, with $35.1 \%(n=142)$ indicating that they would prefer receiving an e-newsletter on a daily basis (see Figure 4).

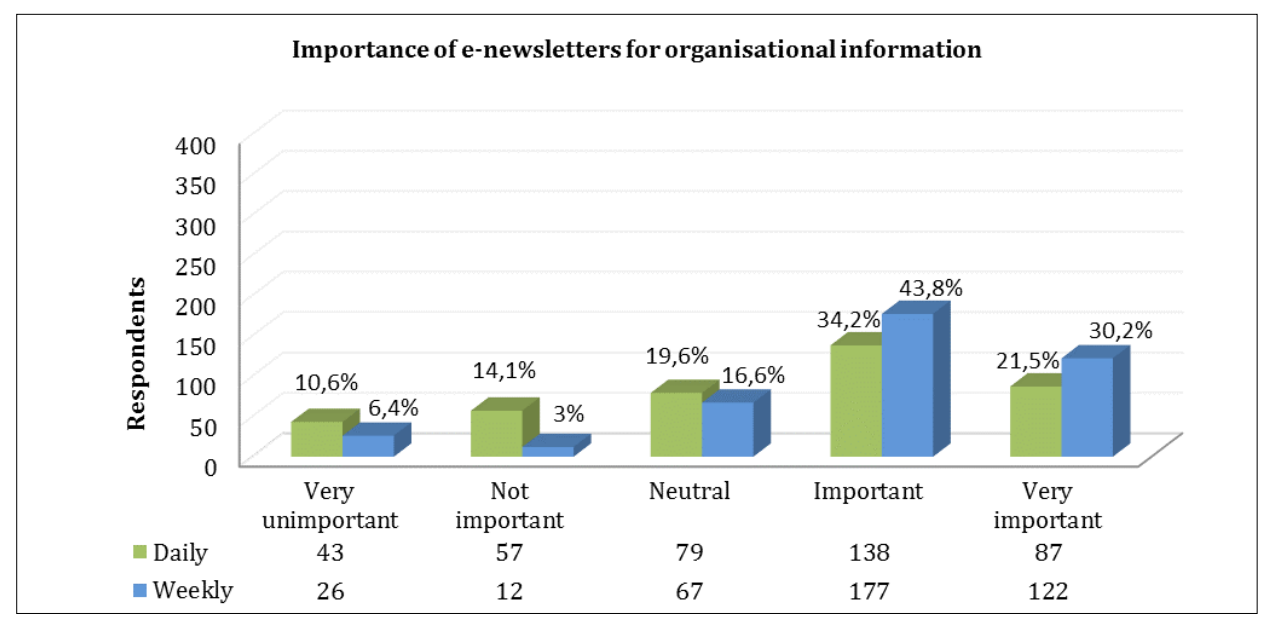

FIGURE 5: IMPORTANCE OF E-NEWSLETTERS FOR

\section{ORGANISATIONAL INFORMATION}

Concerning the importance of daily and weekly e-newsletters as a means to convey organisational information, the majority of the respondents indicated that e-newsletters 
were important or very important with regards to both a daily or weekly e-newsletter (see Figure 5).

\section{DISCUSSION}

From the data it is clear that in terms of the characteristics of e-newsletters, the inclusion of an inspirational quote or "thought for the day" was found to significantly predict whether the respondents would like to receive an e-newsletter or not. Whilst the other characteristics included in the study were rated as important, the inclusion of an inspirational quote in an e-newsletter specifically may increase the likelihood of the respondents wanting to receive an e-newsletter. This result corresponds with the idea that an inspirational quote makes the e-newsletter more appealing to read (Everlytic 2015), or, as Grossman (2016) writes, "Employees won't care about your business until you care about them". Therefore, employees made use of the e-newsletters more so because of the inclusion of a motivational, inspiring, and employee engagement tactic. This was found when examining the respondents' perceptions regarding the characteristics of e-newsletters in general, as well as in relation to the specific institutional e-newsletter they receive as part of communication in the higher institution where they are employed.

With regard to additional factors that may influence the use and the need to receive an e-newsletter, it is clear that there is a high frequency of use for e-newsletters and that e-newsletters, whether they are received daily or weekly, are perceived to be important in ensuring the communication of organisational information. In terms of preference of frequency, the majority of the respondents indicated that they would like to receive a weekly newsletter. If this is considered in light of the fact that the majority of the respondents indicated that they use an e-newsletter once a day and that they prefer an e-newsletter to different channels of communication, it is clear that the e-newsletter may be a key source of information for the respondents. This result links to consistency, relating to how the e-newsletter appears, but also in terms of where it appears (De Greyter 2012). Employees also expect e-newsletters to be delivered at a particular time and at a particular frequency.

In order to ensure a greater likelihood of the respondents wanting to receive an e-newsletter it is thus crucial to ensure that e-newsletters are distributed regularly and that the e-newsletter contains relevant organisational communication and information. In compiling the e-newsletter, apart from the consideration of additional factors such as frequency of distribution and information contained in the e-newsletter, the inclusion of an inspirational quote as a characteristic of the e-newsletter may increase the likelihood that employees would like to receive the e-newsletter, and ultimately the frequency of use of the e-newsletter by employees.

\section{Limitations}

The current study examined the perceptions of the respondents regarding the characteristics of e-newsletters within a specific higher education institution only. 
Thus, the findings may not be generalisable beyond the institution within which the study was conducted.

Further explorative research is suggested to determine whether there might be other factors that could also be important for the expansion of the characteristics of e-newsletters, which based on this study predict the reception and use of e-newsletters.

Regarding sample size, there was a distinct difference between the groups within the sample for the categories of the dependent variable. Whilst the minimum criteria were met for each of the categories (ten respondents per predictor) and logistic regression analysis was robust in terms of differences in variances between the groups, more equally distributed groups may provide a more stable model (Field 2005; Hair et al. 2010).

\section{Recommendations}

Whilst the current study focused specifically on the perceptions and characteristics of e-newsletters within a specific higher education institution in South Africa, further studies could illuminate the specific characteristics that increase the likelihood of use and perceptions regarding the reception of e-newsletters in a myriad of other environments.

Considering the similar odds ratios $(\mathrm{ExpB})$ of other predictors within the model, which are similar to those found for the "thought for the day" predictor (see Table 4 and Table 8), future studies could consider the utilisation of a stepwise logistic regression analysis. A stepwise logistic regression analysis could be used to further analyse the significance of the other characteristics in predicting the perception of receiving and using e-newsletters based on further theoretical review.

In addition, considering the significance of the inclusion of an inspirational quote in e-newsletters and the link to employee engagement, future research could be conducted on the role of e-newsletters in employee engagement and inspirational or motivational quotes.

\section{CONCLUSION}

The current study examined the characteristics of e-newsletters in predicting whether or not the respondents, who work at a higher education institution in South Africa, would like to receive an e-newsletter. It was found that the inclusion of an inspirational quote as a characteristic of an e-newsletter might increase the likelihood of the respondents wanting to receive an e-newsletter. In compiling an e-newsletter, inclusion of this characteristic, along with consideration regarding the frequency of distribution and organisational communication and information, could thus improve the perception of the respondents regarding receiving institutional e-newsletters and the frequency of use of e-newsletters by employees. 


\section{REFERENCES}

De Greyter, S. 2012. 6 easy ways to improve your site's navigation. [Online]. Available at: http://searchengineland.com/6-easy-way-to-improve-your-sites-navigation-132138 [Accessed on 26 September 2017].

Dixon, B. 2012. Social media for school leaders: A comprehensive guide to getting the most out of Facebook, Twitter, and other essential web tools. San Francisco: Jossey-Bass.

Everlytic. 2015. The anatomy of awesome emails 2015. [Online]. Available at: http://www. everlytic.co.za/the-anatomy-of-awesome-emails-2015/the-anatomy-of-awesomeemails-2015/ [Accessed on 11 April 2017].

Field, A. 2005. Discovering statistics using SPSS. (Second edition). London: Sage.

Fourie, L. 2014. Public relations: Theory \& practice. Cape Town: Juta.

Furgison, L. 2017. Tips to creating an engaging internal newsletter. [Online]. Available at: http://www.verticalresponse.com/blog/tips-create-engaging-internal-newsletter/ [Accessed on 26 September 2017].

Gressgård, L.J., Amundsen, O., Aasen, T.M. \& Hansen, K. 2014. Use of information and communication technology to support employee-driven innovation in organizations: A knowledge management perspective. Journal of Knowledge Management 18(4): 633-650.

Grossman, D. 2016. Inspiring quotes from successful CEOs to help you win at employee engagement. [Online]. Available at: http://www.yourthoughtpartner.com/blog/10inspiring-quotes-from-successful-ceos-to-help-you-win-at-employee-engagement [Accessed on 26 September 2017].

Hair, J.F., Black, W.C., Babin, B.J. \& Anderson, R.E. 2010. Multivariate data analyses: A global perspective. (Seventh edition). New Jersey: Pearson Prentice Hall.

Hume, J. 2010. Civicus internal communication toolkit. [Online]. Available at: http:// jessicahume.files.wordpress.com/2010/08/internal_communication_toolkit.pdf [Accessed on 20 December 2012].

Jefferson, S. \& Tanton, S. 2015. Valuable content marketing: How to make quality content your key to success. (Second edition). London: Kogan Page.

Kaufman, M. 2016. Why internal newsletters are so important for your business. [Online]. Available at: http://blog.aespj.com/blog/why-newsletters-are-so-important-for-yourbusiness [Accessed on 26 September 2017].

Kinzey, R.E. 2013. Promoting non-profit organizations: A reputation manage $\urcorner$ ment approach. Oxon: Routledge. [Online]. Available at: http://books.google.co.za/boo ks?id=jfKAAAAAQBAJ\&pg=PA156\&dq=enewsletters+set+up\&hl=en\&sa=X\&ei=Fly XUtbKEKPF7Aai34CoDg\&ved=0CHkQ6AEwCQ\#v=onepage\&q=enewsletters\%20 set\%20up\&f=false [Accessed on 23 November 2016].

Kowlaski, T.J. 2011. Public relations in schools. New Jersey: Pearson.

Little, D. 2011. The importance of your employee newsletter: do not delete. [Online]. Available at: http://www.thecubiclechick.com/2011/03/18/the-importance-of-youremployee-newsletter-do-not-delete/ delete [Accessed on 26 May 2017]. 
Mailbakery.com. 2015. Best design practises for email newsletters. [Online]. Available at: https://mailbakery.com/blog/best-design-practices-for-email-newsletters/ [Accessed on 26 September 2017].

Men, L.R. 2014. Why leadership matters to internal communication: Linking transformational leadership, symmetrical communication and employee outcomes. Journal of Public Relations Research 26: 256-279. https://doi.org/10.1080/1062726X.2014.908719

Men, L.R. \& Hung-Baesecke, C.F. 2015. Engaging employees in China: The impact of communication channels, organizational transparency, and authenticity. Corporate Communications: An International Journal 20(4): 448-467. https://doi.org/10.1108/ CCIJ-11-2014-0079

Modlabs. 2014. The importance of embedding images in email newsletters. [Online]. Available at: https://www.modlabs.com/sugarcrm-modules-blog/the-importance-ofembedding-images-in-email-newsletters [Accessed on 26 September 2017].

Molenaar, C. 2012. E-marketing: Applications of information technology and the internet within marketing. New York, NY: Routledge. https://doi.org/10.4324/9780203805602

Murphy, J. 2014. Why your company needs a quarterly newsletter to engage employees. [Online]. Available at: http://themurphyagency.com/why-your-company-needs-aquarterly-newsletter/ [Accessed on 23 June 2017].

MyHub. 2017. Employee engagement quotations. [Online]. Available at: https:// www.myhubintranet.com/employee-engagement-quotations/ [Accessed on 26 September 2017].

Newsom, D. \& Haynes, J. 2011. Public relations writing: Form \& style. (Ninth edition). New York: Wadsworth/Cengage Learning.

Nyerere, J. \& Friso, V. 2013. Forums for dialogue between university and industry: A case for Kenyatta University, Kenya and University of Padua, Italy. European Journal of Training and Development 37(3): 662-677. https://doi.org/10.1108/ EJTD-10-2012-0060

Paxson, P. 2010. Media communications and media studies: An introduction. London: Continuum International. [Online]. Available at: http://books.google.co.za/books? id=RusUVdLjxrsC\&printsec=frontcover\&dq=communication+media\&hl=en\&sa=X\& ei=VEqXUpHUKMLE7AadmoG4Bw\&ved=0CE4Q6AEwBA\#v=onepage\& $q \& f=$ false [Accessed on 28 November 2016].

Smith, R.D. 2013. Strategic planning for public relations. (Fourth edition). New York: Routledge. https://doi.org/10.4324/9780203081242

Snapcomms. 2017. Internal newsletter content suggestions. [Online]. Available at: https://www.snapcomms.com/solutions/internal-newsletter-ideas [Accessed on 26 September 2017].

Vidgen,R.,Sims, J.\&Powell,P.2011.Understandinge-mailoverload.JournalofCommunication Management 15(1): 84-98. https://doi.org/10.1108/13632541111105277

Welch, M. 2015. Internal communication education: A historical study. Journal of Communication Management 19(4): 388-405. 